\title{
THE INFLUENCE OF BRAND IMAGE AND RESTAURANT ATTRIBUTES TOWARDS CUSTOMER SATISFACTION AT PEKKIO RESTAURANT
}

\author{
Oei Natalia Marcella Rinaldus \& Sonata Christian \\ Universitas Ciputra Surabaya, Surabaya, Indonesia
}

\begin{abstract}
In this globalization era, food service industry as restaurant that provide the basic of human needs has been well developed. The development of food industry has given a huge contribution to the social and environment aspects (Franceschelli et al, 2018). Pekkio restaurant is one of the restaurants in Surabaya that sell Singapore chinese cuisine in Pakuwon Mall Surabaya. In order to survive in this industry, Pekkio restaurant continuously develop their performance to increase the customer satisfaction. With the purpose to find out the factors that influence customer satisfaction, this research aims to discover whether brand image, food quality, service quality, and atmospherics have significant influence towards customer satisfaction of Pekkio restaurant. Therefore, researcher conducted an online survey that are distributed to the samples using 5-point Likert-scale. The population is unknown thus, the researcher use special method from Roa (2016) and the sample become 97. Moreover, the obtained data will be analysed using Multiple Linear Regression. The result shows that food quality and service quality have significant influence towards customer satisfaction of Pekkio restaurant. However, brand image and atmospherics don't significantly influence customer satisfaction at Pekkio restaurant . Albeit, there are positive relationship of brand image and atmospherics towards customer satisfaction of Pekkio restaurant.
\end{abstract}

Keywords: brand image, food quality, service quality, atmospherics, and customer satisfaction

\section{INTRODUCTION}

In this globalization era, food service industry as restaurant that provide the basic of human needs has been well developed. The development of food industry has given a huge contribution to the social and environment aspects (Franceschelli et al, 2018). Global Agricultural Network (2019) assessed the total contribution of food service to Gross Domestic Product (GDP) has reached $\$ 22.1$ billion or 2.18 percent of the GDP in 2017. The growth record was about 6.9 percent which was dominated by the sector of casual restaurants, food stalls and the vendor of street-food restaurant.

*Corresponding Author.

e-mail: onatalia01@student.ciputra.ac.id
Pekkio is a Singapore chinese cuisine restaurant which was established on the first of May 2018. Located on 2M floor, Little Tokyo, Surabaya, Pekkio restaurant is well-known with the tag line of "The best chicken salted egg in the town" that specialize on the salted egg sauce. Most of the menu is targeted for millennials and family.

Since Pekkio has planned to open a new branch, the owner wants to know the impact of brand image that has been built by the restaurant towards customer satisfaction. However, Pekkio believes there are other factors that influence customer satisfaction such as food quality, service quality, and the interior design 
Oei Natalia Marcella Rinaldus \& Sonata Christian / The Influence of Brand Image and Restaurant Attributes towards Customer Satisfaction at Pekkio Restaurant / JEE, Vol. 9, No. 2, September 2020, pp 123-134

of the restaurant. In order to improve Pekkio performance, this research is conducted to contribute feedbacks which can be used to create new strategy.

The researcher wants to ensure whether those factors play big role on the satisfaction of Pekkio customers. This interesting result of the pre-survey encourages the researcher to have a deeper understanding and the knowledge of the influence of brand image, food quality, service quality and atmosphere towards Customer Satisfaction of Pekkio Restaurant.

According to the previous research conducted by Shahzadi et al (2018), aimed to examine the correlation between restaurant key attributes, customer satisfaction, and behavioral intention. This research used regression and gap analysis by collecting data through selfadministered questionnaire, with 296 customers of the fine dining restaurants of Pakistan. This research is chosen as previous study because its similar area of examination which is food industry restaurant and the similar independent variable which are food quality, service quality, and atmospheric quality. Moreover, it used customer satisfaction as mediation variable which will be used as dependent variable in this research. Its findings discovered the important role of restaurant attributes towards behavioural intention which was mediated by customer satisfaction. In addition, the findings indicated food taste and environmental sanitation are the fundamental of the succeed of restaurant in Pakistan.

\section{METHOD}

This research uses quantitative approach by collecting primary data using questionnaires to find the influential factor of customer satisfaction. According to Goertzen, M. J. (2017), the definition of quantitative research methods are concerned with collecting and analyzing structured data which can be represented numerically using statistical techniques to answer. The data will be processed by Statistical Product and Service Solution (SPSS).

According to Chinomona \& Maziriri (2017), in order to measure attitudes, knowledge, perceptions, values, and behavioural changes, a structured questionnaire commonly used a five-point Likert scale ranging from $1=$ strongly disagree to $5=$ strongly agree. The result of quantitative methods are able to explain an issue or phenomenon through assembly data in numerical form and analyze the contribution of mathematical methods in particular statistics. The variables used in this research include brand awareness, food quality, service quality, and atmosphere.

\section{Population and Sample}

Rahi (2017), defined population as the entire number of individuals as object observed that is expected to understand the case. Based on the selected population, there is a process of selection namely sampling by selecting segment of the population to do examination. Sample is defined as a part of the number and characteristics of the population (Priyono, 2017).

In determining the sample, the researcher uses purposive sampling to specify the sample by determine specific characteristics that have to be completed by the research objectives to answer the problems. The respondents of the purposive sampling will be people who have been experienced of buying food more than two times from Pekkio restaurant. In order to calculate the sample of unknown population, the researcher uses special method from Roa (2016), that will define as below: 
$\mathrm{n}=$ Sample size

$\mathrm{Z}=$ The sample confidence level needed in the research, with a $=5 \%$ (percentage of confidence set is $95 \%)$, so $Z=1.96$

$\mu=$ Margin of error, the tolerable error level. (set on 5\%)

Based on the previous formula, the results will be: $n=Z^{2} / 4 / \mu^{2}=1.96 / 4(0.1)^{2}=96.04$ (rounded to be 97 )

\section{Types and Resources}

Based on Kabir (2016), data collection method is divided into two which are:

\section{a. Primary data}

Data that collected through questionnaires, interviews, or experiments from the research problem of the study. This technique enables the researcher to specify the amount of data and the exact data that should be collected. Moreover, the researcher is able to verify the data personally.

\section{b. Secondary data}

Previous data that have been collected by the government, market research agencies, company, individual or other research parties that are able to be accessed by the researcher. The main advantage of using secondary data is the data have been collected. Thus, the researcher simply needs to collect the data through internet or other resources related to the subsequent research.

\section{Data Collection}

The data are collected through two methods which are:

\section{a. Questionnaire}

The researcher uses questionnaire to collect the data by asking related question to the problems. According to Queiros et al. (2017), questionnaire are a research technique to collect data directly through a set of questions in certain order which is distributed to associate respondents. This technique mostly used by quantitative approach, since it enable researcher to obtain a given phenomenon, through the formulation of questions that reflect the opinions, perceptions and behaviors of a group of individuals.

\section{b. Literature}

Correlational researches are used as an exploratory technique to discover the relationship between two variables. Moreover, literature aid the researcher to have a deeper understanding about the theoretical knowledge and field-based to support the study (Queiros et al, 2017).

\section{Multiple Regression Analysis}

In order to discover the influence of multiple independent variables to a dependent variable, the researcher used multiple regression analysis to examine the data (Lind et al, 2017). The formulation is described as:

$$
Y=a+\beta_{1} X_{1}+\beta_{2} X_{2}+\beta_{3} X_{3}+\beta_{4} X_{4}+e
$$

Where:

$\mathrm{Y}=$ Customer Satisfaction

$a \quad=$ Constanta

$\beta_{1,2,3,4}=$ Regression Coefficient

$e \quad=$ Error

$X_{1}=$ Brand Image

$X_{2}=$ Food Quality

$X_{3} \quad=$ Service Quality

$X_{4} \quad=$ Atmospherics 
Oei Natalia Marcella Rinaldus \& Sonata Christian / The Influence of Brand Image and Restaurant Attributes towards Customer Satisfaction at Pekkio Restaurant / JEE, Vol. 9, No. 2, September 2020, pp 123-134

\section{Multicollinearity Test}

Multicollinearity or near-linear dependence appears when there is correlation between two or more variables. This test is used to examine the correlation between variables through testing the value of Variance Inflation Factor (VIF) and tolerance. The formulation of VIF are described as: $V I F=\frac{1}{1-R_{i}^{2}}$

Multicollinearity can be discovered by testing the tolerance for each independent variable. Jamal (2017), defined tolerance as the amount of variability in an independent variable that didn't explained by the other independent variables. There will be no multicollinearity when the VIF value is less than 10 along with the tolerance above 0.10 .

\section{Normality test}

According to Mishra et al (2019), normality test a requirement for statistical tests to discover the normal distribution of independent and dependent variable. The most popular methods that commonly used are the KolmogorovSmirnov test and the Shapiro-Wilk test.

Those methods enable to be conducted in statistical software "SPSS" by analyse, descriptive statistics, explore, plots and normality plots with tests. The researcher uses the Kolmogorov-Smirnov test because the sample of this research is above 50. The variables will be called as normally distributed when the residual significant is above 0.05 .

\section{Heteroscedasticity Test}

Heteroscedasticity test is commonly used in cases of linear regression to discover the difference of the residual variance between the observations. Heteroscedasticity is a problem when ordinary least squares (OLS) regression indicate the constant variance (homoscedasticity) all of the residual from the population. Heteroscedasticity can be discovered using Glejser test. There is no problem of heteroscedasticity in the research when the significance is above 0.05 (Farrar, 2018).

\section{Model Fit Test (F Statistic Test)}

The $\mathrm{F}$ test of overall significance aims to indicate whether the linear regression model provides a better fit to the data than a model that contains zero independent variable.There is significant effect between independent variables and the dependent variable when the $F$ significant value is d" 0.05 (Lind et al, 2017).

\section{Partial Significance Test (t Statistic Test)}

Partial significance test aims to discover the significance effect of the independent variables partially toward dependent variable. There is significant effect between independent variables partially and the dependent variables when the $\mathrm{t}$ significant value is d" 0.05 (Lind et al, 2017).

\section{Coefficient of Correlation (R) and Coeffi- cient of Determination $\left(R^{2}\right)$}

The coefficient of correlation $(R)$ indicates the linear relationship between.two or more independent variables and dependent variable on the range of 0 to 1 . The linear relationship is stronger..when the $R$ value is closer to 1 . Coefficient of determination $\left(R^{2}\right)$ is a percentage that indicates the data point fall in the.result of the line. Values of 0 or 1 will indicate the regression line either all or none of the data (Lind et al, 2017). 
Oei Natalia Marcella Rinaldus \& Sonata Christian / The Influence of Brand Image and Restaurant Attributes towards Customer Satisfaction at Pekkio Restaurant / JEE, Vol. 9, No. 2, September 2020, pp 123-134

\section{RESULTS}

\section{Respondents Characteristic}

Based on the processed data, the respondent characteristic according to respondent's gender. The result shows that there are 46 people or $47.4 \%$ from the whole percentage that are male, and 51 people or $52.6 \%$ are female. Therefore, female are dominated for the result of the questionnaire.

According to the processed data, 91 people or $93.8 \%$ are in the age of 20 to 30 , which is categorized as millennials that was born in between 1990 to 2000 . Following with 5 people or $5.2 \%$ are in the age below 20 and 1 person or $1 \%$ is in the age of more than 30 . This clarifies that the respondent in this research is dominated by millennials.

\section{Descriptive Analysis}

Descriptive analysis will be used in this research to systematically describe the result of the survey using statistic. There are four independent variables used in this research which are brand image, food quality, service quality and atmospherics. While the dependent variable used for this research is customer satisfaction. According to Sugiyono in Novansa \& Ali (2017), the criteria for the respondent's response will be measured by the following formula:

$\frac{\text { Maximum Interval }- \text { Minimum Interval }}{\Sigma \text { Interval }}=\frac{5-1}{5}=0.8$

Based on the formula, the researcher will evaluate the data according to 5 different criteria with the interval of 0.8 difference in number. The evaluation criteria is described as the table below.
Table 1 Interval Evaluation Criteria

\begin{tabular}{cc}
\hline Interval & Evaluation \\
$1-1.80$ & Strongly Disagree \\
$1.81-2.59$ & Disagree \\
$2.60-3.39$ & Somewhat Agree \\
$3.4-4.19$ & Agree \\
$4.2-5$ & Strongly Agree \\
\hline
\end{tabular}

Source: Survey (Data Processed)

\section{a. Brand image}

Table 2 Brand Image Processed Result

\begin{tabular}{|c|c|c|c|c|}
\hline Indicator & Statement & Mean & Category & $\begin{array}{c}\text { Std. } \\
\text { Deviation }\end{array}$ \\
\hline $\mathrm{X} 1.1$ & $\begin{array}{l}\text { I have a good impression } \\
\text { of the overall image of } \\
\text { Pekkio restaurant. }\end{array}$ & 4.21 & $\begin{array}{l}\text { Strongly } \\
\text { Agree }\end{array}$ & .558 \\
\hline $\mathrm{X} 1.2$ & $\begin{array}{l}\text { I want to buy food at Pek- } \\
\text { kio restaurant because of } \\
\text { the overall image of the } \\
\text { food including the appe- } \\
\text { arance of the packaging }\end{array}$ & 4.20 & $\begin{array}{l}\text { Strongly } \\
\text { Agree }\end{array}$ & .589 \\
\hline $\mathrm{X} 1.3$ & $\begin{array}{l}\text { I receive a high social sta- } \\
\text { tus when I eat at Pekkio } \\
\text { restaurant }\end{array}$ & 3.81 & Agree & .928 \\
\hline & Average & 4.07 & Agree & .691 \\
\hline
\end{tabular}

Source: Data Processed

Based on the processed data, brand image as the first independent variable, that has been processed through SPSS indicate the high number of mean which resulting Agree in the category. Mean is the average number of respondents' answer. The average mean of the indicators is 4.07 , shows that the variable given by the researcher is supported by the samples. Therefore, the researcher concludes that all the samples overall agree with the given variable. $\mathrm{X} 1.1$ has the most mean with 4.21 which proves that indicator X1.1 is the major indicator for customers to define brand image.

In the other hand, X1.3 has the least mean which means there is no correlation in the customers' social status when they enjoy food at Pekkio restaurant. However, X1.3 has the highest standard deviation, which means the 
Oei Natalia Marcella Rinaldus \& Sonata Christian / The Influence of Brand Image and Restaurant Attributes towards Customer Satisfaction at Pekkio Restaurant / JEE, Vol. 9, No. 2, September 2020, pp 123-134

Table 3 Food Quality Processed Result

\begin{tabular}{clccc}
\hline Indicator & \multicolumn{1}{c}{ Mean } & Category & Std. Deviation \\
\hline X2.1 & $\begin{array}{l}\text { I enjoy the food at Pekkio restaurant } \\
\text { because it is fresh. }\end{array}$ & 4.16 & Agree & .624 \\
X2.2 & $\begin{array}{l}\text { I enjoy the food at Pekkio restaurant } \\
\text { because it has a good texture. }\end{array}$ & 4.12 & Agree & .617 \\
X2.3 & $\begin{array}{l}\text { I enjoy the food at Pekkio restaurant } \\
\text { because it smells good }\end{array}$ & 4.09 & Agree & .792 \\
X2.4 & $\begin{array}{l}\text { I enjoy the taste of the food at Pekkio } \\
\text { Restaurant because is delicious. }\end{array}$ & 4.23 & Strongly Agree & .700 \\
X2.5 & $\begin{array}{l}\text { I enjoy the food at Pekkio Restaurant } \\
\text { because it is enriched with nutrition. }\end{array}$ & 3.90 & Agree & .757 \\
X2.6 & $\begin{array}{l}\text { I was offered by various menu from } \\
\text { Pekkio restaurant. }\end{array}$ & 3.96 & Agree & .841 \\
X2.7 & $\begin{array}{l}\text { I am satisfied with the food display of } \\
\text { Pekkio restaurant. }\end{array}$ & 4.12 & Agree & .711 \\
X2.8 & $\begin{array}{l}\text { I am satisfied with the serving size of } \\
\text { food at Pekkio restaurant. }\end{array}$ & 4.06 & Agree & .801 \\
\hline & $\quad$ Average & Agree & .730 \\
\hline
\end{tabular}

Source: Data Processed

Table 4 Service Quality Processed Result

\begin{tabular}{|c|c|c|c|c|}
\hline Indicator & Statement & Mean & Category & $\begin{array}{c}\text { Std. } \\
\text { Deviation }\end{array}$ \\
\hline X3.1 & $\begin{array}{l}\text { I am satisfied with the facility of Pekkio } \\
\text { restaurant. }\end{array}$ & 4.08 & Agree & .731 \\
\hline $\mathrm{X} 3.2$ & $\begin{array}{l}\text { I am satisfied with the services of the Pekkio } \\
\text { restaurant that present my order timely. }\end{array}$ & 4.01 & Agree & .669 \\
\hline X3.3 & $\begin{array}{l}\text { I am satisfied with the responsiveness services of } \\
\text { Pekkio restaurant }\end{array}$ & 3.99 & Agree & .729 \\
\hline X3.4 & $\begin{array}{l}\text { I am satisfied with the courtesy of Pekkio } \\
\text { restaurant staff. }\end{array}$ & 3.92 & Agree & .773 \\
\hline $\mathrm{X} 3.5$ & $\begin{array}{l}\text { I am satisfied with the services of Pekkio } \\
\text { Restaurant that are able understand me. }\end{array}$ & 3.99 & Agree & .729 \\
\hline \multirow[t]{2}{*}{ X3.6 } & $\begin{array}{l}\text { I am satisfied with the services of Pekkio } \\
\text { Restaurant that are able to deliver message } \\
\text { properly. }\end{array}$ & 4.02 & Agree & .790 \\
\hline & Average & 4.00 & Agree & .736 \\
\hline
\end{tabular}

Source: Data Processed

least homogenous answer amongst the other indicators and X1.1 as the most homogenous.

\section{b. Food quality}

Based on the processed data, Food Quality, which has been processed through SPSS indi- cate the overall samples agree with the given indicators. By the average mean of the indicators, which is 4.08 , shows that the indicators given by the researcher is supported by the samples. The researcher can conclude that each indicator is similarly able to support the Food Quality variable. With the average standard 
Oei Natalia Marcella Rinaldus \& Sonata Christian / The Influence of Brand Image and Restaurant Attributes towards Customer Satisfaction at Pekkio Restaurant / JEE, Vol. 9, No. 2, September 2020, pp 123-134

Table 5 Atmospherics Processed Result

\begin{tabular}{clccc}
\hline Indicator & \multicolumn{1}{c}{ Statement } & Mean & Category & Std. Deviation \\
\hline X4.1 & $\begin{array}{l}\text { I feel convenient with the space utility } \\
\text { of Pekkio restaurant. }\end{array}$ & 4.07 & Agree & .725 \\
X4.2 & $\begin{array}{l}\text { I had a beautiful memory because of the } \\
\text { colour of Pekkio's interior design. }\end{array}$ & 3.87 & Agree & .874 \\
X4.3 & $\begin{array}{l}\text { I enjoy a good lighting at Pekkio } \\
\text { restaurant. }\end{array}$ & 4.00 & Agree & .692 \\
X4.4 & $\begin{array}{l}\text { I enjoy a clean environment at Pekkio } \\
\text { restaurant. }\end{array}$ & 4.27 & Strongly Agree & .715 \\
X4.5 & $\begin{array}{l}\text { I enjoy a fit temperature at Pekkio } \\
\text { restaurant }\end{array}$ & 4.15 & Agree & .697 \\
X4.6 & $\begin{array}{l}\text { I enjoy good music that make me } \\
\text { comfortable. }\end{array}$ & 4.05 & Agree & .795 \\
X4.7 & $\begin{array}{l}\text { I feel convenient having } \\
\text { communication with the staff. } \\
\text { I didn't feel disrupt by the crowd or } \\
\text { other customers }\end{array}$ & 4.08 & Agree & .745 \\
\hline \multicolumn{1}{c}{ Average } & 4.94 & Agree & .814 \\
\hline
\end{tabular}

Source: Data Processed

deviation of 0.730 indicates that the data are consistent, with X2.2 as the most homogenous.

\section{c. Service quality}

According to the processed data, Service Quality, which has been processed through the SPSS indicate the overall samples agree with the given indicators. The average mean for this variable is 4.00 which means the samples agree with the indicators given by the researcher to support the variable. X3.4 has the least mean which make X3.4 the least considered indicator. The average standard deviation as shown above is 0.736 , with $\mathrm{X} 3.2$ as the most homogenous. The researcher concluded that each indicator is able to point out the aspect of the Service Quality variable.

\section{d. Atmospherics}

Based on the processed data, Atmospherics, which has been processed through SPSS indicate the overall samples agree with the given indicators. By the average mean of the indicators, which is 4.05 , shows that the indicators given by the researcher is supported by the samples. The researcher can conclude that each indicator is similarly able to support the Atmospherics variable. With the average standard deviation of 0.757 indicates that the data are consistent, with X4.3 as the most homogenous.

\section{e. Customer satisfaction}

The data processed shows dependent variable in this research which is Customer Satisfaction, that has been processed through SPSS. Most of the samples agree to the indicators of the variables, with a few people who disagree with the given indicators by the researcher. The average mean of the indicators is 4.01 which considered as agree. Y3 has the highest standard deviation which means it has the most homogenous answer amongst the other indicators in this variable, while Y2 has the lowest standard deviation which means it has more 
Oei Natalia Marcella Rinaldus \& Sonata Christian / The Influence of Brand Image and Restaurant Attributes towards Customer Satisfaction at Pekkio Restaurant / JEE, Vol. 9, No. 2, September 2020, pp 123-134

Table 6 Dependent Variable Processed Result

\begin{tabular}{clccc}
\hline Indicator & \multicolumn{1}{c}{ Statement } & Mean & Category & $\begin{array}{c}\text { Std. } \\
\text { Deviation }\end{array}$ \\
\hline Y1 & $\begin{array}{l}\text { I'm satisfied with the overall experience } \\
\text { at Pekkio restaurant }\end{array}$ & 4.23 & Strongly Agree & .729 \\
Y2 & $\begin{array}{l}\text { I have a good memory at Pekkio restau- } \\
\text { rant }\end{array}$ & 4.05 & Agree & .698 \\
Y3 & $\begin{array}{l}\text { I feel a good mood after having expe- } \\
\text { rienced at Pekkio restaurant }\end{array}$ & 3.77 & Agree & .810 \\
\hline$\quad$ Average & 4.01 & Agree & .745 \\
\hline
\end{tabular}

Source: Data Processed

consistent answer amongst the other indicators in this variable.

\section{Validity and Reliability}

The researcher uses the Pearson Correlations theory that stated the Sig. value must be equal to or below 0.05. Based on data processed, the test result shows a number of 0.000 for each indicator which are Brand Image, Food Quality, Service Quality, Atmospherics and Customer Satisfaction. Based on the result, the researcher concluded that all indicators in the variables are considered valid.

\section{Reliability Test Results}

The researcher uses Cronbach's Alpha theory to evaluate the reliability of each indicator. The alpha value is considered reliable when the number is above 0.60. The lowest test result shows that the Cronbach's Alpha is 0.620, which is more than 0.60 , means that the data can be considered reliable.

\section{Multiple Regression Analysis}

According to the formulation on appendix, the multiple regression equation will be:

$y=0.571+0.124 X 1+0.343 X 2+0.364 X 3+0.021 X 4$

$$
\begin{aligned}
& \mathrm{Y}=\text { Customer Satisfaction } \\
& \mathrm{X} 1=\text { Brand Image } \\
& \mathrm{X} 3=\text { Service Quality } \\
& \mathrm{X} 2=\text { Food Quality } \\
& \mathrm{X} 4=\text { Atmospherics }
\end{aligned}
$$

As shown in the equation above, the researcher used unstandardized coefficients in this research. The positive value in Brand Image, Food Quality, Service Quality, Atmospherics indicate that each variable has positive relationship with Customer Satisfaction as the dependent variable.

\section{Model Fit Test (F Test)}

According to the processed data, it shows that all variables including Brand Image, Food Quality, Service Quality, and Atmospherics significantly influence Customer Satisfaction with F value 12.652 and significant value of 0.000 . It is proved that the $\mathrm{F}$ is $<0.05$, making all independent variables Value have significant impact towards Customer Satisfaction of Pekkio restaurant.

\section{Partial Test ( $\mathrm{t}$ Test)}

According to the processed data, that is similar to the regression table, explain the partial significance of every independent variables. Stated that Food Quality and Service Quality 
are both significantly influencing the dependent variable, with each have significance value of 0.022 and 0.017 , which both are lower than 0,05 . Both of the variable met the criteria needed to be considered significant in influencing Customer Satisfaction. However, Brand Image and Atmospherics shown that have more than 0.05 significant value, which mean the variable did not meet the criteria needed to be considered significant in influencing Customer Satisfaction. Therefore, the researcher concluded that both Food Quality and Service Quality have significant influence towards Customer Satisfaction of Pekkio Restaurant while Brand Image and Atmospherics didn't have significant influence towards Customer Satisfaction of Pekkio restaurant.

\section{Coefficient of Correlation (R) and Coeffi- cient of Determination (R2) Test Result}

According to the processed data, the test result numbers of Coefficient of Correlation (R) and Coefficient of Determination test (R2). The value of $\mathrm{R}$ is shown to be 0.596 , which is a positive value, explaining that the independent variables have positive influence and relationship towards the dependent variables. Therefore, the researcher concluded that when Brand Image, Food Quality, Service Quality, and Atmospherics improve then there will be enhancement in Customer Satisfaction of Pekkio restaurant as well, because there is positive relationship in five variables.

While the number of 0.355 shown in adjusted $\mathrm{R}$ square shows the ability of the independent variables to affect and influence the dependent variable. Therefore, the researcher concluded that four of the independent variables have mildly ability to influence the dependent variable, because the percentage become
$35.5 \%$, which is below the half of the maximum value. While the other $73.5 \%$ are other independent variables which not discussed in the research.

\section{Classical Assumption Test}

\section{a. Multicollinearity test}

The researcher uses multicollinearity test in this research based on the Variance Inflation Factors (VIF) number, which should be less than 10. The processed data in Table 4.15 shown that the VIF value of all of the variables are $1.620,1.821,2.231$, and 1.980 which is below 10. Therefore, the researcher concluded that there are no multicollinearity in the data.

\section{b. Normality test}

Based on the processed data, the significant value of the Kolmogorov-Smirnov Test is 0.000 , which is below 0.05 . The researcher then concluded that this research is normally distributed because it has more than 0.05 significant value which is 0.20 .

\section{c. Heteroscedasticity test}

According to the processed data, the significant value for Brand Image is 0.205, Food Quality is 0.837 , Service Quality is .384, Atmospherics is .488 which mean there is no heteroscedasticity in the all variables.

\section{DISCUSSION}

This research has been conducted by processing 97 data samples, in which samples are distributed randomly to repeat customer of Pekkio restaurant all around Indonesia. According to table 4.1, the respondents of the ques- 
Oei Natalia Marcella Rinaldus \& Sonata Christian / The Influence of Brand Image and Restaurant Attributes towards Customer Satisfaction at Pekkio Restaurant / JEE, Vol. 9, No. 2, September 2020, pp 123-134

tionnaire are dominated by female in the age of 20 to 30 which are categorized as millennials. Mostly the customers receive new information about promotion from social media such as Instagram and they brought their friends to enjoy the food together. Therefore, worth of mouth is so important in this case. Moreover, the data collection was done using Google Form.

\section{The Influence of Brand Image towards Cus- tomer Satisfaction}

According to the processed data, the coefficient of brand image variable is 0.124 which is positive. Thus, it shows that there is a positive relationship between brand image and customer satisfaction. This statement is supported by Chen (2017), that the positive influence of brand image. towards purchase intention will affect the .customers' evaluation which indicated in the level of satisfaction.

However, for the $\mathrm{t}$ value, the significant value for brand image is 0.304 which is higher than 0.05 . It means that brand image is not significantly influence customer satisfaction. The result didn't compatible with the researcher initial hypothesis (H1) which stated "Brand Image significantly influence Customer Satisfaction". The result is supported by previous research that conducted by Tandon et al., (2017) which stated that brand image doesn't significantly influence customer satisfaction. Moreover, this result might be influenced by the population chosen in the research. The population in this research is Pekkio repeat customer who have tried Pekkio either two times or more, thus they didn't concern about the brand image because they already trust the Pekkio restaurant to do the next purchasing.

Based on the result in descriptive analysis, people seem to give higher score on the ques- tion X1.1 with mean of 4.21 stated that Pekkio own a good brand image. It indicates that people agree on the statement of they have a good impression of the overall image of Pekkio restaurant. On the other hand, X1.3 is the least considered indicators by people, which stated that Pekkio restaurant give an impression of high social status. In this case, Pekkio restaurant can use this as feedback to create a better image for the overall restaurant to enhance customers' perception.

According to the descriptive data, the researcher can make an assumption that Pekkio is a trusted restaurant because most respondents answered agree and strongly agree in brand image indicators. This assumption can be supported by the fact that Brand Image has most indicator which the mean is categorized as strongly agree

\section{The Influence of Food Quality towards Cus- tomer Satisfaction}

Based on Table 4.11, the coefficient of perceived product quality is 0.343 , which shows that food quality has a positive .relationship with customer satisfaction. The positive relationship means. when food quality increase, the customer satisfaction will increase, and vice versa. It is supported by Erkmen \& Hancer (2018), that proposed to better understand how customers form their brand preference for fine dining restaurants to acknowledge the importance of restaurant attributes.

Moreover, the significant value in $t$ statistic test of food quality is 0.02 which is less than 0.05 . Thus, the researcher concluded that the result answered the problem which is food quality has significant influence towards customer satisfaction of Pekkio restaurant. This statement is supported by Erkmen \& Hancer 
(2018), that food quality has significant and positive impact towards customer satisfaction.

According to the result in descriptive analysis, the highest mean score on the question is X2.4 with mean of 4.23 stated that Pekkio's food have a good taste. It indicates that people agree on the statement of they enjoy the taste of the food at Pekkio Restaurant because it is delicious. However, the mean for statement X2.5 has the least number which stated that customers enjoy the food at Pekkio Restaurant because it is enriched with nutrition. Therefore, Pekkio restaurant can add nutrition information on their menu or add more healthy ingredients to their food.

\section{The Influence of Service Quality towards Customer Satisfaction}

The Table 4.11 shows that the coefficient of service quality is 0.364 , which shows that service quality has a positive .relationship with customer satisfaction. Therefore, when service quality increase, the customer satisfaction will increase, and vice versa. It is supported by Erkmen \& Hancer (2018), which find service quality is important aspect that significantly influence customer satisfaction.

Moreover, the significant value in $t$ statistic test of service quality is 0.01 which is less than 0.05 . Thus, the researcher concluded that the result answered the problem which is service quality has significant influence towards customer satisfaction of Pekkio restaurant. This statement is supported by Erkmen \& Hancer (2018), that service quality played a significant role in forming the brand image in the minds of restaurant guests.

Based on the result in descriptive analysis, the highest mean score on the question is X3.1 with mean of 4.08 stated that Pekkio service has a good facility. Therefore, Pekkio have to maintain their performance in providing good service facility to the customers. In the other hand, the mean for statement X3.4 has the least number which stated that customers satisfied with the courtesy of Pekkio restaurant staff. It means that Pekkio restaurant should improve their hospitality. In this case, Pekkio restaurant staff can give a hospitable welcome and thank you greeting to customers with a brightly expression.

\section{The Influence of Atmospherics towards Cus- tomer Satisfaction}

Based on the processed data, the coefficient of atmospherics is 0.02 , which shows that atmospherics has a positive .relationship with customer satisfaction. Therefore, when atmospherics increase, the customer satisfaction will increase, and conversely. It is supported by Shahzadi (2018), to explore the relationship between restaurant key attributes, customer satisfaction, and behavioral intentions. Therefore, a good atmosphere will affect the customers' convenience.

Moreover, the significant value in $t$ statistic test of atmospherics is 0.865 which is more than 0.05 . Therefore, the researcher concluded that the result doesn't match the problem which mean atmospherics didn't significantly influence customer satisfaction of Pekkio restaurant. This statement is supported by the research findings of Yang (2017), that ambience does not directly affect the review enjoyment yet the food and beverage images are the most important factors affecting both usefulness and enjoyment. Thus, the atmospheres is not the main factor that influence customer satisfaction yet it can be the supporting factor. 
Oei Natalia Marcella Rinaldus \& Sonata Christian / The Influence of Brand Image and Restaurant Attributes towards Customer Satisfaction at Pekkio Restaurant / JEE, Vol. 9, No. 2, September 2020, pp 123-134

According to the result in descriptive analysis, the highest mean score on the question is X4.4 with mean of 4.27 stated that Pekkio's food have a clean environment. While the least mean is X4.2 with mean of 3.87 which state that customers get beautiful memory because of the colour of Pekkio's interior design. This the least considered indicators, can be suggestion to Pekkio restaurant to create more memorable interior design.

\section{REFERENCES}

Chinomona, R., \& Maziriri, E. T. (2017). The Influence of Brand Awareness, Brand Association and Product Quality on Brand Loyalty and Repurchase Intention: a Case of Male Consumers for Cosmetic Brands in South Africa. Journal of Business \& Retail Management Research, 12(01).

Farrar, T. J. (2018). An Omnibus Test for Heteroscedasticity using Radial Stationarity and Data Depth, 1-8.

Franceschelli, M. V., Santoro, G., \& Candelo, E. (2018). Business Model Innovation for Sustainability: a Food Start-up Case Study. British Food Journal, 120(10), 2483-2494.

Kabir, S. M. S (2016). Basic Guidelines for Research: An Introductory Approach for All Disciplines ( $1^{\text {th }}$ ed.) 204-208. Chitta- gong, Bangladesh: Book Zone Publication.

Lind, D. A., Marchal, W . G., \& Mason, R. D. (2017). Statistical Techniques in Business and Economics (16 ${ }^{\text {th }}$ ed.), 276-387. New York: McGraw-Hill/Irwin.

Priyono, P. I. (2017). Effect of Quality Products, Services and Brand on Customer Satisfaction at McDonald's, 5(2). DOI: 10. 4172/2375-4389.1000247

Queiros, A., Faria, D., \& Almeida, F. (2017). Strengths and Limitations of Qualitative and Quantitative Research Methods, 3(9). https://doi.org/10.5281/zenodo.887089.

Rahi, S. (2017). Research Design and Methods: A Systematic Review of Research Paradigms, Sampling Issues, and Instruments Development. International Journal of Economics of Management Sciences, 06(02).

Roa, M. (2016). Green Technologies for Offshore Industry. Offshore Technology Conference Asia. https://doi.org/10.4043/ 26859-ms.

Shahzadi, M., Malik, S. A., Ahmad, M., \& Shabbir, A. (2018). Perceptions of Fine Dining Restaurants in Pakistan. International Journal of Quality \& Reliability Management, 35(3), 635-655. 